\title{
LA CAPILLA DEL COLEGIO DE OVIEDO, TEMPLO DE LA CIENCIA Y DE LA VIRTUD
}

\author{
POR

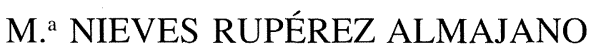

\begin{abstract}
Este artículo analiza el programa iconográfico de la capilla dedicada a santo Toribio de Mogrovejo, cuyo motivo central fue la representación de las ciencias. A través del mismo, el Colegio de Oviedo, en clara rivalidad con la Universidad, se atribuye un papel que correspondía a aquella y ofrece de su institución una imagen ideal, como impulsora de la sabiduría y de una vida virtuosa. La intervención de José de Churriguera en la elección concreta de las alegorías explicaría la presencia de la Arquitectura entre las disciplinas liberales y la aparente arbitrariedad de las imágenes simbólicas, que en lo esencial ilustran las facultades primordiales de la Universidad salmantina del Antiguo Régimen.

Palabras clave: Santo Toribio de Morgrovejo. José de Churriguera. Programa iconográfico. Colegio de Oviedo. Universidad de Salamanca. Arquitectura. Alegoría.
\end{abstract}

The author analyzes the iconographic program of the chapel dedicated to saint Toribio of Mogrovejo, the central motive of which was the representation of the sciences. Through this cycle the Colegio de Oviedo, in clear rivalry with the University, assumed the role corresponding to the latter institution, and offered an ideal image of the college as generator of wisdom and the virtuous life. José de Churriguera's intervention in the selection of the specific allegories helps to explain the presence of Architecture among the liberal disciplines and the apparent arbitrariness of the symbolic images, which essentially illustrate the original faculties of the University of Salamanca in the Early Modern Age.

Key words: Saint Toribio of Mogrovejo. José de Churriguera. Iconographic program. Colegio de Oviedo. University of Salamanca. Architecture. Allegory.

La beatificación en 1679 de Toribio Alfonso de Mogrovejo, arzobispo de Lima y ex-colegial del Mayor de Oviedo de la Universidad de Salamanca, ofreció a su antiguo Colegio el motivo para construir una nueva capilla. La destrucción del edificio durante la Guerra de la Independencia y la desaparición de sus restos en los años siguientes ha impedido valorar adecuadamente esta obra, cuyo proceso constructivo intentamos pergeñar en otra ocasión '. Pero su significado e importancia quedan sin duda resaltados cuando se la contempla desde otras perspectivas, menos dependientes de la existencia física del inmueble de lo que precisa un análisis formal o estético.

\footnotetext{
${ }^{\prime}$ Rupérez Almajano, M.N., «José de Churriguera en Salamanca (1692-1699)», en Anuario del Departamento de Historia y Teoría del Arte. Universidad Autónoma de Madrid. vol. IX-X, 1997-98, pp. 212-215.
}

AEA, LXXV, 2002, 300, pp. 397 a 405 
Por encima de su finalidad religiosa, este templo se va a erigir en el símbolo más elocuente de la imagen que el Colegio quiere ofrecer de sí mismo al exterior: un «palacio de las ciencias», al mismo tiempo que un «seminario de virtud».

Este contenido, claramente propagandístico, se expresaba fundamentalmente a través del programa iconográfico que completaba la arquitectura del edificio, pero no era el único. La iniciativa de construir a fines del seiscientos, en un momento general de crisis, una capilla con toda la magnificencia posible y elevado coste económico, constituye en sí misma una clara manifestación del poder social de los Colegios Mayores y de su prepotencia frente a la propia Universidad $^{2}$, que la iconografía no hace más que reafirmar.

Indirectamente este proyecto puede servir también para ilustrar la difusión que va alcanzando la concepción científica de la arquitectura. La vertiente intelectual de ésta no sólo se destaca mediante la exaltación del tracista, sino especialmente a través de algunas de las alegorías materializadas en sus esculturas, mucho más eficaces para la transmisión de las ideas a nivel popular que las imágenes grabadas o los textos teóricos.

Los datos esenciales sobre las figuras que ornamentaban el exterior de la capilla del Colegio de Oviedo nos los ofrece don Nicolás Antonio Guerrero Martínez en una extensa publicación dedicada a relatar los festejos celebrados con motivo de la canonización de Santo Toribio de Mogrovejo en $1727^{3}$. En ella no pierde ocasión de ensalzar al Colegio en el que residía como huésped, y la capilla dedicada al santo era una construcción al alcance de todas las miradas de la que aquel podía enorgullecerse. De hecho su «soberbia torre» o cimborrio constituía el principal símbolo de identidad de este Colegio Mayor en el espacio público de la ciudad.

A falta de un conocimiento completo de sus características estructurales, estéticas y formales, que sólo podemos intuir por los rasgos que nos proporciona ese mismo autor y las condiciones de obligación contenidas en dos escrituras ${ }^{4}$, nos consta la elevada inversión que supuso su fábrica, que debió superar los 25.000 ducados. Casi la mitad de esta cantidad fue aportada por don Melchor de Navarra y Rocafull, Duque de Palata, antiguo colegial de Oviedo y virrey de Perú de 1681 a 1689. Fue él quien consiguió de la iglesia de Lima una reliquia del brazo del entonces beato para su Colegio; junto con la reliquia le envió doce mil ducados para «que con menos dificultad pudiese prevenir templo en que con más ornato se adorase» y una lámpara de mil ochocientas onzas de plata que luciese a los pies de «su santo hermano» 5 .

Es difícil saber por los testimonios que tenemos si la idea de edificar la capilla partió de esta donación o si, como parece más probable, esta vino a secundar con generosidad una decisión que había tomado ya el Colegio de Oviedo. Lo que está claro es que se trata de una construcción de nueva planta, concebida desde un principio como una «urna» o «trono del santo», es decir, un lugar especial dedicado preferentemente a honrar a su santo colegial y a exponer

\footnotetext{
${ }^{2}$ En este sentido la arquitectura - como ya anotó la profesora Carabias- constituye, junto con las ceremonias, el protocolo, el atuendo o el modo de vida un elemento más, y no el menos importante aunque a veces se olvide, a través del cual los colegiales construyen su imagen pública, su particular «representación» o modo de «ser-percibido», dentro de las formas de teatralización esenciales en la sociedad del Antiguo Régimen (Cf. Roger Chartier, El mundo como representación. Barcelona, Gedisa, 1992, pp. 57-59). Carabias Torres, Ana M. ${ }^{\text {, }, ~ « P o d e r ~ y ~ c o n o c i m i e n t o . ~ U n i v e r s i d a d ~ c o n t r a ~ c o l e g i o s », ~ e n ~}$ Las Universidades Hispánicas: de la Monarquía de los Austrias al centralismo liberal. Junta de Castilla y León, Universidad de Salamanca, 2000, vol. I, pp. 117-118.

${ }^{3}$ Guerrero Martínez Rubio, N.A., El phénix de las becas, Santo Toribio Alphonso Mogrovejo... Salamanca, viuda de Gregorio Ortiz, 1728. Mogrovejo fue canonizado el 10 de diciembre de 1726 pero la noticia no llegó al Colegio hasta el 14 de enero de 1727.

${ }^{4}$ Se trata de la obligación de 1699 por la que Joaquín de Churriguera se compromete a concluir la capilla iniciada por su hermano, y de una intervención muy posterior - de 1743- para rehacer el chapitel que cubría la media naranja. Archivo Histórico Provincial de Salamanca (A.H.P.S.), Protocolo 3040, ff. 589r.-592v. y prot. 3316, ff. 190r.-192v.

${ }^{5}$ Guerrero Martínez, ob. cit., libro I, pág. 25, libro II, pág. 59.
} 
sus reliquias a la veneración de los fieles ${ }^{6}$, sin relación con la capilla existente y muy por encima de las necesidades religiosas de los colegiales.

Sin embargo, bien porque la dotación prometida por el duque de Palata no se hiciese efectiva de modo inmediato, bien porque se considerase insuficiente para las pretensiones del Colegio de Oviedo, endeudado en esas fechas por las obras de ampliación de su hospedería ${ }^{7}$, el inicio de la nueva capilla se pospuso todavía varios años, hasta 1694. Parece que entonces el Colegio no escatimó gastos, sumando a lo ofrecido por el duque de Palata otras cantidades entregadas voluntariamente o exigidas a los antiguos colegiales y el dinero de sus propias rentas, con las que avala la imposición de varios censos que proporcionan la liquidez necesaria para hacer frente a los pagos ${ }^{8}$.

La nueva construcción, con acceso independiente desde el exterior, se debió levantar junto a la fachada principal del viejo colegio, en la que destacaban como primordial adorno los «hermosos balcones de la rectoral». La existencia de una pequeña plazuela abierta delante potenciaba su visibilidad y proporcionaba al conjunto un mayor empaque ${ }^{9}$.

Como es sabido, tanto el proyecto como la ejecución de esta capilla fueron encargados a José de Churriguera. La propia figura del tracista se convierte al cabo de pocos años, olvidados los problemas reales que ocasiona la fábrica, en uno de los argumentos principales para acreditar el mérito de la obra. Señala Guerrero que en ella «quiso ostentar todo su ingenio aquel mejor Archimedes, que el que asombró al mundo, don Joseph de Churriguera, cuya habilidad pasmando a las naciones, ha sabido ostentar, que quantos afamados ingenios vocea en la arquitectura nuestra Europa no pueden competirle, por más que se desvelen». Con notable exageración acaba llamándole el «Vitrubio de nuestros tiempos» ${ }^{10}$, o lo que es lo mismo, el arquitecto por antonomasia ${ }^{11}$, equiparable con aquel por su destreza y conocimientos arquitectónicos.

Estos epítetos estaban respaldados, sin embargo, por un edificio singular, que carecía de término comparación en la ciudad ${ }^{12}$, en el que José de Churriguera pudo desarrollar su creatividad sin mayor limitación que el espacio disponible, no demasiado amplio. Del resultado no solo se benefició el Colegio de Oviedo, que adquiere una imagen monumental renovada, más en consonancia con su influencia y poder reales ${ }^{13}$, sino también el propio artista cuyo reconocimiento fue prácticamente unánime en ese momento. Con esta iniciativa el Colegio de Oviedo se adelantó en su afán de sobresalir al resto de los mayores, que a lo largo del XvIII van entrando a competir en este mismo juego de las apariencias.

\footnotetext{
${ }^{6}$ El Colegio se ocupó posteriormente de ir incrementando estas reliquias con otros huesos y la mitra con que había sido enterrado el santo obispo. Esta se la proporcionó don Gonzalo Vaquedano a través de las gestiones de don Sebastián García Romero, del Consejo de Castilla, que la remitió a su colegio en 1718, después de que otros dos colegiales de San Bartolomé y del Arzobispo hubiesen hablado a aquel de la capilla «que para monumento de la fama de nuestro Santo» había erigido el Colegio de Oviedo. Guerrero Martínez, ob. cit., libro segundo, págs. 61-62. Después de la canonización logró un hueso del brazo y otro de una costilla. Archivo Diocesano de Salamanca (A.D.S.), Caja Colegios Mayores y Menores.

${ }^{7}$ El presupuesto inicial de esta obra, que consistía sobre todo en la ampliación de algunas dependencias del Colegio en la zona suroccidental, destinada a hospedería, era algo inferior a 70.000 reales. Se comenzó en agosto de 1675 pero dio lugar a un largo pleito que se alargó hasta los años 90. Para hacer frente al gasto el Colegio impuso sobre sus rentas diversos censos por valor de 6.000 ducados. A.H.P.S., Prot. 5336, ff. 146 y ss. Archivo de la Universidad de Salamanca (A.U.Sa.), Fondo universitario, leg. 2344, ff. 111 y ss. Cf. Rupérez, pág. 212.

${ }^{8}$ Rupérez Almajano, M.N., art. cit. págs. 213 y 226.

${ }^{9}$ Guerrero Martínez, ob. cit., libro III, págs. 6-7.

${ }^{10}$ Ibídem, libro II, pág. 59.

"Es una de las significaciones que adquiere frecuentemente la imagen de Vitrubio. Sobre este aspecto, Vitrubio, Los diez libros de Arquitectura. Madrid, Alianza, 1995, introducción de Delfín Rodríguez Ruiz, pp. 14 y ss.

${ }^{12}$ Dice Guerrero que «en Salamanca (Ciudad, cuyos edificios desaparecen las glorias de los más voceados) no se encuentra de su especie fábrica que la iguale». Libro II, pág. 59.

${ }^{13} \mathrm{La}$ imagen que proporciona la arquitectura es mucho más permanente y por tanto más eficaz como instrumento propagandístico que la que proporcionan las celebraciones públicas y ceremonias, por naturaleza efímeras, con ser éstas muy destacadas.
} 
El hecho de que José de Churriguera cite expresamente esta capilla como uno de sus principales méritos a la hora de optar a la vacante de aparejador mayor de las Obras Reales en $1698^{14}$, no deja duda sobre la autoría del proyecto arquitectónico. Pero en él jugaba también un papel fundamental la escultura. Ésta se concentraba esencialmente en el exterior del templo y lo más probable es que Churriguera recibiese indicaciones precisas por parte de los colegiales sobre la iconografía de tipo alegórico que debía aparecer, si bien debieron dejarle cierta libertad para disponerla y concretarla, como veremos.

José de Churriguera trazó una capilla de «arquitectura romana y limpia, toda bien labrada de cantería», con presbiterio semicircular, articulada en los ángulos con pilastras cajeadas provistas de capiteles compuestos. Desconocemos si el tipo de planta utilizado era longitudinal o bien central, en razón de su finalidad acorde con el simbolismo asociado tradicionalmente a estas formas ${ }^{15}$, pero en ella sobresalía, tanto interior como exteriormente, una media naranja apoyada en un ochavo de cantería y cubierta con un ligero chapitel provisto de linterna y aguja.

Al exterior la capilla estaba adornada por dos «corredores» de piedra, uno en el arranque mismo del ochavo y el otro dispuesto «al quadrado», lo que podría inducir de nuevo a suponer una planta central. Los «corredores» se coronaban por doce «bellas estatuas de las ciencias de cuerpos naturales sobre sus pedestales bien guarnecidos». Cada una llevaba el distintivo que permitía identificarlas sin error. Las ciencias representadas fueron las siguientes ${ }^{16}$ :

La Gramática con un libro en la mano izquierda y en la diestra una vara.

La Lógica con un «libro sin juego, ni manecillas y un clavo que le atraviesa».

La Filosofía con un libro abierto en la mano.

La Geometría con un cuerpo geométrico irregular en la diestra.

La Astronomía con dos globos en la mano y a los pies.

La Retórica con una figura en la mano siniestra apuntándola con el índice la derecha.

La Astrología con una esfera en la mano y elevada la vista.

La Aritmética con un papel en las manos y en él diversidad de números.

La Música con un violón rodeado de cifras.

La Metafísica con una culebra en la mano diestra, un sol en el pecho, y en la cabeza una corona.

La Arquitectura con un compás en la mano, reclinada sobre una columna jónica, a quien rodean algunas trazas.

Y la Cosmografía con un cuadrante y un papel en la mano.

El programa iconográfico se completaba con tres esculturas más situadas en las hornacinas que se abrían en la fachada. En el centro, sobre el arco de la puerta que daba acceso al interior, una estatua de piedra de Toribio Alfonso de Mogrovejo vestido con manto y toga; a ambos lados las estatuas de la Teología y la Jurisprudencia, alusivas no sólo a los estudios del beato -licenciado en cánones y buen teólogo - sino también a la formación esencial de los colegiales de Oviedo, cuyas becas inicialmente estaban previstas para nueve teólogos y nueve canonistas ${ }^{17}$.

\footnotetext{
${ }^{14}$ Rivera, J., «Nuevos datos documentales de Teodoro Ardemans, José de Churriguera y otros arquitectos barrocos cortesanos», en B.S.A.A., núm. XLVIII, 1982, pp. 449-450. También lo recuerda Joaquín de Churriguera al solicitar el puesto de maestro mayor de la catedral (A. Rodríguez G. de Ceballos, «Joaquín de Churriguera y la primera cúpula de la Catedral Nueva de Salamanca», en Estudios de Arte. Homenaje al profesor Martín González. Universidad de Valladolid, 1995, pág. 249).

${ }^{15}$ Lotz, Wolfgang, «Notas sobre las iglesias de planta central del Renacimiento», en La arquitectura del Renacimiento en Italia. Estudios. Madrid, Hermann Blume, 1985, pág. 69.

${ }^{16}$ Cf. Guerrero Martínez, ob. cit., libro II, págs. 59-60.

${ }^{17}$ Carabias Torres, A., Colegios Mayores: Centros de poder. Universidad de Salamanca, 1986, tomo II, 490 y 884 y ss. Posteriormente redujo las becas de teólogos a cuatro para incrementar las de juristas que ofrecían mayores posibilidades de promoción social. Esta alteración de las becas originales fue denunciada por Pérez Bayer como una de las corruptelas. Pérez Bayer, Francisco, Por la libertad de la literatura española (1785). Alicante, 1991.
} 
No es nuevo el empleo de representaciones de las ciencias en edificios dedicados al estudio, particularmente en las bibliotecas, de las que es un ejemplo excepcional la real biblioteca del monasterio del Escorial ${ }^{18}$. Sin embargo, antes de fines del siglo XVII no es frecuente encontrar este tipo de motivos en un exterior, y lo que aún resulta más llamativo del caso que nos ocupa es que esta iconografía enteramente profana aparezca en la capilla ${ }^{19}$, desvirtuando o al menos olvidando por completo el sentido religioso del templo, para configurar una imagen enaltecida y en cierto modo «sacralizada» de la institución a la que pertenece: el Colegio de Oviedo.

Un repertorio figurativo similar —ciencias impartidas en el edificio junto con los monarcas fundadores o protectores de la institución- se utiliza pocos años después en la fachada monumental que levanta la Universidad de Valladolid en 1715; las diferencias existentes no impiden considerar que la fuente de inspiración inicial pudo ser el programa iconográfico abordado en la capilla del colegio salmantino. No hay que olvidar que las

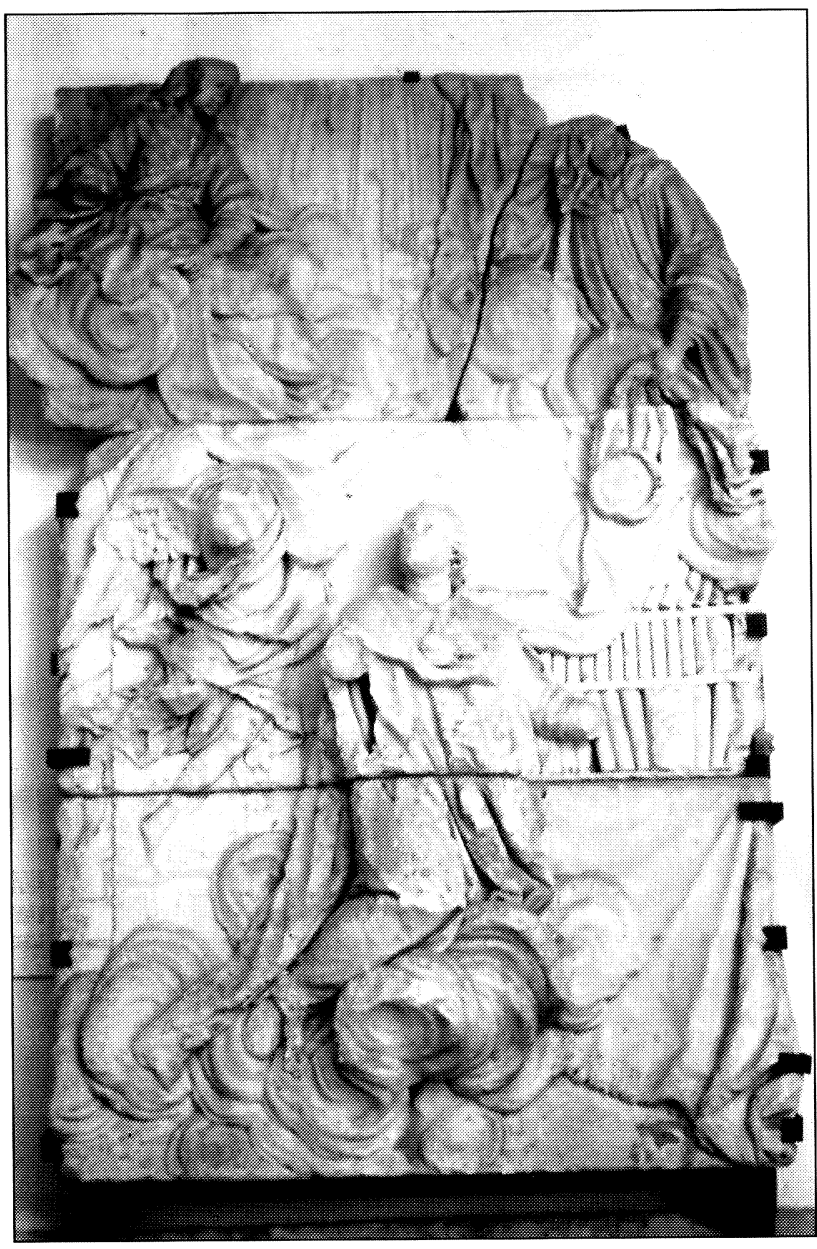

Fig. 1. Santo Toribio recibiendo la beca colegial. Luis Salvador Carmona. 1756. Mármol de Yelves. Depositada en el Museo de Bellas Artes de Salamanca. trazas para aquella fachada fueron dadas por el carmelita fray Pedro de la Visitación, que coincidió en Salamanca con José de Churriguera y permaneció en la capital charra después de concluida esta capilla ${ }^{20}$. También la portada principal del colegio de mareantes de San Telmo en Sevilla, emprendida por Leonardo de Figueroa en 1721, incorpora representaciones de las disciplinas enseñadas en el mismo ${ }^{21}$, y

\footnotetext{
${ }^{18}$ El tema de su decoración pictórica son las siete Artes Liberales —el Trivium y el Quadrivium-, presididas por la Filosofía y la Teología situadas en los testeros. Taylor, René, Arquitectura y magia. Consideraciones sobre la idea de El Escorial. Madrid, Siruela, 1992, pp. 37 y ss. Bustamante García, Agustín, «Imágenes de la Sabiduría: La decoración de la biblioteca escurialense», en Cuadernos de Arte e Iconografía, tomo VI, núm. 11, 1993, pp. 338-346.

${ }^{19}$ Hoy en día se pueden ver representaciones de la poesía, la filosofía, la teología, la ciencia, la religión y la elocuencia en la fachada norte de la capilla de la Sorbona, pero se trata de estatuas del siglo xIx.

${ }^{20}$ Martín González, Juan José, «La fachada principal de la Universidad», en Historia de la Universidad de Valladolid. Valladolid, Universidad, 1989, pp. 673-681. Fray Pedro de la Visitación estaba al frente de la obra de la iglesia que construía su Orden en Salamanca. En ese tiempo dio trazas también para otros edificios -el convento de Santa Clara, los cuarteles...- y fue solicitado para emitir diversos informes periciales — entre otros por el Cabildo de la catedral—, dada su buena fama. (A.H.P.S, Prot. 4787, fol. 427, A.D.S., Actas capitulares, libro 45, fol. 482).

${ }^{21}$ Las esculturas corrieron a cargo de un equipo de escultores dirigido por Pedro Duque Cornejo entre 1731-1733. Cf. Falcón Márquez, Teodoro, El palacio de San Telmo. Sevilla, 1991. Del mismo autor, «Jesucristo como modelo en el programa iconográfico del palacio de San Telmo de Sevilla», en Cuadernos de Arte e Iconografía, tomo IV, núm. 7, 1990, pp. 256-261.
} 
esta alusión referencial a la función está presente en los programas decorativos proyectados para otros edificios docentes en fechas más tardías ${ }^{22}$.

Según estas realizaciones posteriores, en especial la de Valladolid, cabe interpretar que el Colegio de Oviedo está en gran medida suplantando o al menos atribuyéndose un papel que correspondía a la Universidad de Salamanca, en clara rivalidad con ella ${ }^{23}$, desde el momento en que se muestra a los ojos de todos como garante no sólo de la Teología o de la Jurisprudencia, las dos disciplinas primordiales de la Universidad salmantina del Antiguo Régimen, sino también de todo el saber, representado simbólicamente por una gran diversidad de ciencias que corresponden a otras tantas cátedras impartidas en aquella. A esta interpretación da pie también Guerrero al anotar brevemente que santo Toribio se «adornó con la Ciencia, que en mi colegio aprendió, su grande alma» ${ }^{24}$.

Además de las dos Facultades mayores, destacadas por el lugar privilegiado que ocupan en la fachada, estaban bien ilustradas las cátedras de Artes y Humanidades a través de las alegorías de la Filosofía y de las siete Artes Liberales que integraban el Trivium y el Quadrivium medieval (Gramática, Retórica, Lógica —en lugar de la Dialéctica-, Aritmética, Música, Geometría y Astronomía). Comparativamente llama la atención la sobrevaloración de algunas disciplinas frente al peso real que tenían en la Universidad. De este modo, si puede resultar comprensible la representación de la Metafísica, materia obligada en la facultad de Artes y calificada por Ripa como «la reina» de todas las ciencias que pueden alcanzarse con las luces naturales ${ }^{25}$, es más sorprendente que aparezcan la Astrología y la Cosmología, que podían considerarse citadas a través de la Astronomía o de las disciplinas matemáticas. Todas ellas estaban englobadas en una única cátedra, que si bien tuvo momentos de esplendor en otro tiempo presentaba ahora signos evidentes de decadencia ${ }^{26}$. Pero todavía es más llamativo la presencia de una alegoría específica de la Arquitectura, que aparece así claramente reconocida como ciencia, al mismo nivel que otras enseñanzas liberales, tal como defendía en el plano teórico la literatura artística ${ }^{27}$.

La inquietud intelectual y la dedicación al estudio que preside toda la vida de Toribio Alfonso de Mogrovejo, podía justificar el motivo de las ciencias como tema central de la capilla a él dedicada, imágenes simbólicas que, como acabamos de decir, reflejan también los distintos saberes de una universidad tradicional, de los que el Colegio de Oviedo se presenta como depositario. Lo que ya no resulta tan probable es que los colegiales de Oviedo, juristas y teólogos que aspiraban a los altos cargos de la administración del Estado y de la

\footnotetext{
${ }^{22}$ A título de ejemplo, la fachada de la nueva Universidad de Santiago proyectada por Miguel Caaveiro en 1798, que no llegó a realizarse, incluía la representación de motivos alegóricos de las ciencias para que quedase patente «el destino del edificio». VV.AA., El patrimonio histórico de la Universidad de Santiago de Compostela. Universidad de Santiago, 1995, tomo I, pág. 52.

${ }^{23}$ El enfrentamiento entre los Colegios Mayores y la Universidad es una constante en la Edad Moderna, que presenta otras manifestaciones apuntadas por Carabias Torres, «Poder y conocimiento...», art. cit.

${ }^{24}$ Guerrero Martínez, ob. cit., libro III, pág. 4.

${ }^{25}$ Ripa, Cesare, Iconología. Madrid, Akal, 1987, tomo II, pág. 86. Esta realeza viene expresada por la corona, aunque en poco más coincidían las personificaciones de las Ciencias descritas por Guerrero con las de Ripa, a juzgar por las diferencias de atributos y actitudes.

${ }^{26}$ Esta decadencia era común a las universidades de Salamanca, Valladolid y Alcalá, frente al vanguardismo que muestra en el xv con el astrónomo y matemático judío Abraham Zacut, o en el xvi. Fernández Álvarez, M.; Robles Carcedo, L.; Rodríguez-San Pedro, L.E., La Universidad de Salamanca. Salamanca, Universidad, 1989, tomo I, pp. 45, 87, $128-129$.

${ }^{27}$ Una visión sintética en García Morales, $M^{\mathrm{a}}$ V., La figura del arquitecto en el siglo XVII. Madrid, UNED, 1990. En este contexto la representación de la Geometría y de las otras artes del «Quadrivium» que aparecen en muchos tratados de arquitectura como símbolos equivalentes de ésta y con atributos intercambiables, no habría sido suficiente para resaltar su liberalidad. Sobre esta ambivalencia de las alegorías, Toajas Roger, M. ${ }^{a}$ Angeles, «La arquitectura como la geometría: sobre su representación en la tratadística de los siglos XVI y XVII», en Cuadernos de Arte e Iconografía, tomo II, núm. 4 (1989), pp. 163-170.
}

$A E A, \mathrm{LXXV}, 2002,300$, pp. 397 a 405 
Iglesia ${ }^{28}$, tuviesen especial interés en destacar el carácter científico, y con ello la nobleza, de la arquitectura.

Cabe pensar que la idea de representar esta «ciencia» se debió a la iniciativa de José de Churriguera. De este modo resaltaba el aspecto intelectual — científico-, de su propio trabajo, expresado gráficamente en las trazas que rodeaban a la figura, frente a la actividad puramente mecánica de los encargados de ejecutarlas. Documentos escritos posteriores muestran que poseía una conciencia profesional nada artesanal, apoyada en una sólida formación teórica autodidacta, y que participó activamente en el debate abierto para establecer la condición liberal de las artes, en especial de la Escultura y Arquitectura, utilizando argumentos similares a los de su coetáneo Ardemans ${ }^{29}$. Pudo ser también él —una vez discutido con el cliente el programa decorativo- quien, en último caso, decidiese las personificaciones concretas de las Ciencias que iban a culminar las balaustradas, lo que explicaría la aparente arbitrariedad de la elección. No deja de ser curioso que muchas de ellas vengan a simbolizar los conocimientos teóricos que según Vitrubio debían adornar al arquitecto, reiterados también de una u otra manera por todos los tratados de los siglos Xvi y XviI que Churriguera pudo tener a su alcance: competente en geometría y aritmética, lector de filósofos, entendido en música, ilustrado en jurisprudencia, perito en astrología y en los movimientos del cosmos, versado en historia y en gramática, documentado en medicina ${ }^{30}$, etc.

Independientemente de la mayor o menor intervención del artista en el repertorio iconográfico, el resultado final sería el mismo: el Colegio de Oviedo, y en concreto su capilla, se exhibe públicamente como palacio o templo de las ciencias, pero no sólo eso. Presidiendo la fachada de la capilla — como ya señalamos_ aparecía el titular de la misma: el entonces beato Toribio de Mogrovejo, pero no como arzobispo de Lima, sino como colegial, modelo ejemplar de todos los hijos de esta Casa en los que la formación científica estaría inseparablemente unida a una vida virtuosa, favorecidas ambas por el Colegio. Esta vinculación entre ciencia y virtud resulta más patente por ser la capilla, y no otras dependencias del colegio, la destinata-

\footnotetext{
${ }^{28}$ Entre los que habitaban el Colegio en el momento de edificar la capilla podemos señalar a don José de Arce y Arrieta que fue presidente de la Chancillería de Granada, don Marcelo Santos de San Pedro, que ocupó un oficio en la Inquisición, don Bartolomé Henao y Larreategui, que llegó a la presidencia de la chancillería de Granada, don Francisco Francos y Monroy, que ocupó cátedras cursatorias de Leyes, Instituta y Digesto, antes de ser nombrado catedrático de Vísperas de Leyes en 1698, ocupando al año siguiente la alcaldía del crimen de la Chancillería de Valladolid; don Francisco Henao de Larreategui, catedrático de una de las cursatorias de Cánones, y después de Sexto y de Vísperas, siendo promovido en 1699 a la alcaldía del Crimen de la Chancillería de Valladolid. Don Francisco Márquez de Bracamonte y Montalvo, catedrático de las cursatorias de Cánones, Sexto, Vísperas y Decreto, hasta que en 1697 fue promovido a fiscal de la Chancillería de Valladolid. Don Sebastián García Romero, catedrático de Vísperas de Cánones y de Decreto, fue promocionado sucesivamente a la Chancillería de Valladolid, al Consejo de Castilla y a un oficio de la Inquisición. Don Manuel de Junco y Cisneros, obtuvo la cátedra de Decretales y llegó a ser consiliario del Consejo Real de Castilla. Don Lope de la Vega Trelles, catedrático de Víspera de leyes, doctorado en 1794, siendo promovido al año siguiente a fiscal de la Chancillería. Don Pedro Martínez Canseco que fue Magistral de Valladolid. Don Juan Antolino Azogue y don Juan González ocuparon una cursatoria de Artes en el 96 y 99. Esperabé Arteaga, E., Historia pragmática e interna de la Universidad de Salamanca. Salamanca, Impr. Nuñez Izquierdo, 1917, tomo II, pp. 565, 572, 578, 596, 609, Fernández Catón, J.M., «El Colegio Mayor de San Salvador de Oviedo de la Universidad de Salamanca. Catálogo de sus colegiales», en Rev. Studium Legionense, núm. 1, 1960, pp. 259-329. Carabias Torres, A., «Excolegiales mayores en la administración española y americana durante el reinado de Felipe $\mathrm{V}_{\Downarrow,}$ en Estudios de historia social y económica de América. Universidad de Alcalá, núm. 7 (1991), pp. 55-93.

${ }^{29}$ Este aspecto ha sido bien analizado por Bonet Correa, Antonio, «Los retablos de la iglesia de las Calatrava de Madrid. José de Churriguera y Juan de Villanueva padre», en A.E.A., XXXV (1962), pp. 21-49. Vuelve sobre la cuestión, BLASCO ESQUIVIAS, Beatriz,Teodoro Ardemans y su entorno en el cambio de siglo (1661-1726). Aspectos de la arquitectura y el urbanismo madrileños de Felipe II a Carlos III. Ed. Universidad Complutense, Tesis doctorales, 1991, pp. 495 y ss.

${ }^{30}$ Vitrubio, ob. cit., cap. I, pág. 59 y ss. Es decir, el arquitecto debía conocer si no profundamente todas las ciencias, sí al menos en grado razonable, y de ello se hace eco José de Churriguera en su correspondencia con Ardemans diciendo que el tracista debía no sólo dibujar con destreza sino tener conocimientos de historia, perspectiva y otras materias. Bonet Correa, art. cit. pág. 46.
} 
ria de esta iconografía en principio profana, justificada en este caso por la propia vida del santo, ejemplo de una y otra. Sabiduría y piedad serían también las obligaciones que competen a los colegiales, y la imagen — más ajustada a los primeros años fundacionales ${ }^{31}$ — que de sí mismos quieren transmitir en este tiempo frente a una opinión general bien distinta ${ }^{32}$.

La bondad de la dedicación al estudio que ocupa a los colegiales, vuelve a remarcarse mediante la representación, en una pintura situada sobre la tribuna, de un suceso acaecido a Toribio de Mogrovejo durante su estancia en el Colegio de Oviedo: la aparición de la Virgen poniéndole sobre los hombros la beca de colegial en presencia de San Bernardo ${ }^{33}$, que acaba por resolver sus dudas entre permanecer en el mismo o hacerse cisterciense (Fig. 1). Este tema también será el motivo central del bajorrelieve realizado por Luis Salvador Carmona para el retablo de mármol proyectado en $1756^{34}$.

El interior de la capilla estaba adornado además con una rica decoración en relieve trabajada tanto en piedra como en yeso. Destacaban los cuatro escudos de las pechinas y las cuatro tarjetas del anillo, que se encargó de terminar Joaquín de Churriguera en 1699, junto con los modillones de la cornisa o las sartas de las pilastras ${ }^{35}$. Además de esto, en los cuatro lienzos principales, como síntesis de la heroica vida del santo, se dibujaron o pintaron los «geroglyficos más comprehensivos de sus glorias»: un báculo y una mitra, símbolos del arzobispado que ocupó, y una beca y un bonete, alusivos a su condición de colegial.

Sin embargo, el foco principal de atracción era sin duda el presbiterio, donde estaban dispuestas la reliquia y una efigie del santo sobre un altar fabricado al tiempo que el resto de la capilla, como consta documentalmente ${ }^{36}$. Dado que José de Churriguera dirigía la obra y eran reconocidas sus dotes como escultor, él sería el autor de esta imagen. Se trataba de una escultura en madera policromada que satisfizo plenamente al Colegio. Según la descripción que de ella ofrece Guerrero, resaltaba sobre todo su naturalismo. Su rostro, de apacible serenidad, dirigía su atención a un libro que llevaba en la mano derecha, en alusión tanto a su estudiosa vida como a su labor de enseñanza, mientras con la izquierda sostenía el bonete. Santo Toribio estaba, pues, representado con la indumentaria de colegial, con manto y beca, como no podía

\footnotetext{
${ }^{31}$ Por su régimen de vida, dedicación al estudio y selección moral los colegios mayores se han considerado el precedente de los seminarios tridentinos. De hecho el Colegio de Oviedo sirvió de modelo y patrón para el primero de estos seminarios que fundó Santo Toribio en Lima. Rodríguez Valencia, Vicente, Santo Toribio de Mogrovejo. Organizador y apóstol de suramérica. Madrid, CSIC, 1956, tomo I, pág. 104.

${ }^{32}$ En el sermón que predicó el colegial de Oviedo don Gregorio Nieto en 1727 señala al respecto que en el colegio no sólo se aprendía — «como algunos creen»_ vanidad, soberbia y, cuando más, cuatro letras mezcladas con mucha ridícula ceremonia, lo que nos indica cual era el sentir más extendido. Guerrero Martínez, ob. cit., libro III, pág. 199.

${ }^{33}$ Guerrero Martínez, ob. cit., libro primero, pág. 29, Libro segundo, págs. 182, 212. Esta versión muy difundida por el Colegio fue la que acabó prevaleciendo frente a otra primitiva en la que aparecía el santo de rodillas en el suelo en hábito de colegial mayor, y en el plano superior san Bernardo poniéndole la beca y santo Toribio de Liébana, su santo homónimo, dándole la bendición. Cf. Rodríguez Valencia, ob. cit., tomo I, pág. 99. Sin embargo, la iconografía más frecuente del santo lo representa vestido de prelado y rodeado de pobres a los que reparte limosna (Schenone, H.H., Iconografía del arte colonial. Buenos Aires, Fundación Tarea, 1992, vol. II, pág. 765).

${ }^{34}$ Rodríguez G. de Ceballos, A. y Nieto González, J.R., «Aportaciones a Simón Gabilán Tomé», en A.E.A., núm. 213 (1981), pp. 31, 35-36. Durante la ocupación francesa de la ciudad el duque de Ragusa quiso que se salvase de la destrucción el altar y las columnas, lo que ha permitido que se conserve este relieve pese a sus mutilaciones. Se encuentra en el Museo de Bellas Artes de Salamanca (Gallego de Miguel, Amelia, Museo de Bellas Artes de Salamanca. Salamanca, 1975, pág. 19).

${ }^{35}$ Guerrero Martínez, libro segundo, pág. 60: «adornó por dentro el friso de la cornisa, lienzos, y pilastras, entre calles, pechinas, y recinchos de la media naranja de hermosas delicadas targetas, y molduras de media talla». Este autor coincide plenamente con lo refleja la escritura de obligación contraida por Joaquín de Churriguera. A.H.P.S., Prot. 3040, ff. 589r.$592 \mathrm{v}$.

${ }^{36}$ En la información que ofrece el Colegio en 1695 para imponer un censo dice que «está haziendo y redificando de nuebo la capilla... en la qual y su altar, que de nuebo asimismo se a de fabricar, se a de poner la reliquia de santo Thoribio de Mogrobejo,... y la echura del santo de talla de cuerpo entero y otras cosas, para que esté dicha capilla con toda dezencia». A.U.Sa., leg. 2344, fol. 190r.
}

$A E A, \mathrm{LXXV}, 2002,300$, pp. 397 a 405 
ser menos partiendo la iniciativa de unos individuos orgullosos de su privilegiada condición y para los que el traje era la «más propia gala de su virtud» ${ }^{37}$.

$\mathrm{Si}$ antes el arquitecto de la capilla podía ser un nuevo Vitrubio, esta «primorosa» imagen acreditaba al escultor como el Fidias de nuestros tiempos. En cualquier caso la calidad de la obra artística, arquitectónica o escultórica, si prestigiaba a su autor y le podía beneficiar social y económicamente, sobre todo atestiguaba de manera evidente el nivel social superior del comitente.

\footnotetext{
${ }^{37}$ Guerrero Martínez, ob. cit., libro II, pág. 90, tomo III, pág. 8 y 29-31. Dice textualmente este autor en la más extensa de sus alusiones: «las facciones del rostro tan perfectas, que podían asombrar a Praxiteles, la atención cuidadosa, con que guiaba los ojos a las hojas de un bien formado libro, que era empleo discreto de su diestra hazía dudar, si era acción verdadera con que enseñaba, o representación de su estudiosa vida, vivificado al parecer su rostro con el color mas propio, ... con tal ayre apuró su noble habilidad el diestro artífice en la perfecta formación de esta acabada estatua, que aun el alma, que no podía darle, parece que no le falta a su hermosura representada en la viveza grande, con que imita las acciones naturales, ...: lo cierto es, que aunque su insigne autor no huviera publicado su acreditada ciencia en otra obra, que en la de esta primorosa efigie de nuestro santo, podía elevarse a Fidias de nuestros tiempos, pues se advirtió tan ajustada a las reglas de su noble arte, que no las desmentía la distancia, siendo así, que en más celebres estatuarios fue desayre infeliz este tropiezo. Aumentaba a sus primores magestad el nuevo adorno con que se dexó ver en el trage mas propio de nuestro amor, que si con el hechó los fundamentos de su virtud, razón era, le sirviese de gala a su celebridad, ...»
} 